\title{
Pelagic metabolism in eutrophic coastal waters during a late summer period
}

\author{
Kaj Sand-Jensen, Lillian Magelund Jensen*, Steen Marcher, Mads Hansen
}

Freshwater Biological Laboratory, University of Copenhagen, Helsingørsgade 51, DK-3400 Hillerød, Denmark

\begin{abstract}
We measured phytoplankton and bacterial biomass and production at weekly intervals during summer in water samples from 2 sites in the shallow, eutrophic Roskilde Fjord, Denmark. In addition we measured $\mathrm{O}_{2}$-uptake on unfiltered water and size-fractions $<100 \mu \mathrm{m}$ and $<1 \mu \mathrm{m}$. Phytoplankton gross production in the water column was $6.2 \mathrm{~g} \mathrm{O}_{2} \mathrm{~m}^{-2} \mathrm{~d}^{-1}$ at $\operatorname{Stn} 1$ and was balanced by pelagic community respiration $\left(R_{C}, 3.8 \mathrm{~g} \mathrm{O}_{2} \mathrm{~m}^{-2} \mathrm{~d}^{-1}\right)$ and sediment respiration $\left(2.5 \mathrm{~g} \mathrm{O}_{2} \mathrm{~m}^{-2} \mathrm{~d}^{-1}\right)$. Phytoplankton gross respiration $\left(3.0 \mathrm{~g} \mathrm{O}_{2} \mathrm{~m}^{-2} \mathrm{~d}^{-1}\right)$ was temporarily exceeded by pelagic community respiration $\left(3.1 \mathrm{~g} \mathrm{O}_{2} \mathrm{~m}^{-2} \mathrm{~d}^{-1}\right)$ plus sediment respiration $\left(2.0 \mathrm{~g} \mathrm{O}_{2} \mathrm{~m}^{-2} \mathrm{~d}^{-1}\right)$ at $\operatorname{Stn} 2$ where there is additional production by littoral plant communities. Phytoplankters and bacteria together accounted for 72 to $85 \%$ of $R_{C}$ and zooplankters for the remainder Phytoplankters respired a large proportion (ca $30 \%$ of their gross production and were apparently mainly grazed by benthic suspension feeders. Phytoplankters dominated pelagic respiration $\left(50 \%\right.$ of $\left.R_{C}\right)$ at Stn 1 , which has most phytoplankton, while bacteria dominated $\left(44 \%\right.$ of $\left.R_{C}\right)$ at $S \operatorname{tn} 2$. We ascribe the relatively larger respiratory activity of bacteria at Stn 2 to additional supply of organic matter from littoral plant communities and frequent sediment resuspension. The importance of bacteria in the pelagic food web was supported by other findings. Bacterial biomass approached phytoplankton carbon biomass at Stn 2 and bacterial net production in the water column was $10 \%$ (Stn 1) and 35\% (Stn 2) of phytoplankton gross production. Bacterial net production and respiration were linearly related in the bacterial size-fraction $(<1 \mu \mathrm{m})$ with a bacterial growth yield of $47 \%$. We argue that the conversion factors applied to calculate bacterial net production and the mean growth yield attained are reasonable values considering the other measurements of pelagic carbon pools and processes.
\end{abstract}

\section{INTRODUCTION}

New and improved methods of measuring biomass, production and respiration of bacterioplankton have shown that bacteria are important biological components of pelagic environments. Direct cell counts of the number of free-living bacteria and measurements of their biovolume and carbon content demonstrate that bacterial biomass is often high and that bacteria represent a large proportion of biological surfaces in the plankton community (Watson et al. 1977, Peters 1986. Bjørnsen 1987, Simon \& Tilzer 1987). Estimates of bacterial gross production range from 20 to $80 \%$ of the phytoplankton production in lakes (Riemann \& Sendergaard 1986) and 24 to $60 \%$ in marine environments (Fuhrmann \& Azam 1980, 1982, Larsson \& Hagström 1982, Lancelot \& Billen 1984, Ducklow \& Hill 1985).

- Present address: Institute of Biology and Chemistry, University of Roskilde, PO Box 260, DK-4000 Roskilde, Denmark
Finally, about $50 \%$ of plankton community respiration has been found in the bacterial size-fraction in marine coastal waters (Williams 1981) and eutrophic lakes (Schwaerter et al. 1988).

There are currently intensive discussions of the reliability of some of these estimates, particularly those of bacterial net production (Riemann \& Søndergaard 1984. Carman et al. 1988, Robarts \& Wicks 1989) and the proper evaluation of bacterial metabolism in the pelagial food webs (Scavia 1988, Sherr \& Sherr 1988, Strayer 1988). Despite the methodological problems, however, bacterial net production does appear to vary predictably across systems of different trophic status (Cole et al. 1988). In an overview based upon 70 studies, annual bacterial production averaged $30 \%$ of water column annual primary productivity (Cole et al. 1988). Applying a mean growth yield of $50 \%$ (Cole et al. 1988) this result would indicate that $60 \%$ of primary production was fluxed through the bacteria and $30 \%$ was respired. These values are certainly not fixed but 
are likely to vary with the season and properties of particular ecosystems, e.g. the supply of allochthonous compounds, the food web structure, the depth and influence of sediment processes. Though these averages look high, even higher levels of bacterial carbon demands relative to primary production have been reported for some environments (Scavia 1988). Likewise, $50 \%$ of plankton community respiration in the bacterial size-fraction (Williams 1984, Schwaerter et al. 1988) would indicate bacterial carbon demands approaching the level of primary production if most of the organic input is respired in the pelagial and bacterial growth yield is $50 \%$. As pointed out by Strayer (1988), however, it should be realized that organic molecules are consumed and recycled several times through the food web and the flux through the bacteria derives not only from phytoplankton exudates and lysis products but from heterotrophic organisms as well. The total secondary production of heterotrophic organisms may therefore exceed primary production whereas primary production plus allochthonous input should be balanced by respiratory losses and losses of organic compounds from the pelagic. This would give room for a considerable production and respiration of grazing and predatory organisms that form the link to fish populations.

Despite the controversy of bacterial production methods there has been few attempts to evaluate them towards a carbon mass balance (Cole et al. 1989) or to combine them with other measurements of bacterial metabolism. In this context, measurements of community respiration and respiration in the bacterial sizefraction have several advantages. They provide an overall assessment of heterotrophic metabolism directly related to oxidation of organic matter and bacterial net production, and respiration can be measured in the same size-fraction and tested for internal reproducibility and consistency. These combined measurements would allow us to evaluate the importance of bacteria in oxidizing organic material and to calculate bacterial growth efficiency.

In this paper we examined phytoplankton biomass and production, bacterial biomass and production, and dark oxygen consumption of the entire plankton community and of size-fractions smaller than $100 \mathrm{um}$ and $1 \mu \mathrm{m}$ in a eutrophic Danish estuary. The experiments reported here were restricted to 2 eutrophic sites during a late summer period when surface irradiance and temperature were relatively stable. Our objectives were several. First, we determined the distribution of respiration among size-fractions and evaluated the contribution of different organisms and in particular the contribution of small, free-living bacteria to plankton community respiration. Second, we related bacterial net production measured by thymidine incorpo- ration to bacterial respiration in size-fractions less than $1 \mathrm{um}$ and estimated bacterial growth efficiency. Finally, we evaluated the overall autotrophic and heterotrophic metabolism in the plankton community.

\section{MATERIALS AND METHODS}

Study sites. Roskilde Fjord is a nutrient-rich, shallow estuary with low tidal amplitude $(<10 \mathrm{~cm})$ connected with the Kattegat via the outer part of Isefjord, Denmark (Fig. 1 in Jensen et al. 1990). We examined 2 sites in the inner part of the estuary (Stn 1 and Stn 2 in Jensen et al. 1990) at weekly intervals between July 22 and September 2. Water depth was $4.1 \mathrm{~m}$ at Stn 1 and $4.6 \mathrm{~m}$ at Stn 2. Both sites had high phytoplankton and bacterial biomasses and high levels of primary production and plankton community respiration. The benthic animal community was dominated by polychaetes at Stn 1 whereas high densities of mussels Mytilus edulis were found at Stn 2. Further details are given by Borum (1985) and Jensen et al. (1990).

Water samples. Water was collected before noon with a 51 Perspex sampler from 3 depths at Stn 1 and 4 depths at Stn 2 evenly distributed in the usually wellmixed water column. Measurements of plankton community respiration $\left(\mathrm{R}_{\mathrm{C}}\right)$ and bacterial net production (BNP) in the unfiltered samples were started immediately as described previously (Jensen et al. 1990) Laboratory measurements were initiated within 1 to $4 \mathrm{~h}$. Water samples were kept at ambient seawater temperature in insulated boxes during transport. Laboratory incubations were made in bottles under circulation in a thermostated incubator kept at ambient seawater temperature.

Analytical procedure. The following analytical scheme was used for measurements of dark respiration, phytoplankton gross photosynthesis (PGP) and BNP. Dark respiration was measured over $24 \mathrm{~h}$ in unfiltered samples $\left(R_{C}\right)$ and samples filtered through a $100 \mu \mathrm{m}$ mesh-size net $\left(\mathrm{R}_{100}\right)$ and a $1 \mu \mathrm{m}$ Nuclepore filter $\left(R_{1}\right)$. Phytoplankton gross photosynthesis was measured over $2 \mathrm{~h}$ on unfiltered samples (PGPC) and $100 \mu \mathrm{m}\left(\mathrm{PGP}_{100}\right)$ and $1 \mu \mathrm{m}\left(\mathrm{PGP}_{1}\right)$ size-fractions. Bacterial thymidine incorporation as a measure of net production was determined immediately over $0.5 \mathrm{~h}$ in unfiltered samples $\left(B N P_{C}\right)$ and $1 \mu \mathrm{m}$ samples $\left(B P_{1}\right)$. In addition, thymidine incorporation was measured in $1 \mathrm{um}$ filtrates that had been incubated over $24 \mathrm{~h}$ in the incubator in the dark $\left(\mathrm{BNP}_{1}(24)\right)$ to be able to correct for changes in bacterial activity during the $24 \mathrm{~h}$ period used for measurements of respiration in the same sizefraction

Respiration. Respiration was measured in $125 \mathrm{ml}$ darkened Jena glass bottles. The initial and final oxy- 
gen concentrations were measured on triplicate bottles for every size-fractions with a micro-Winkler technique using starch as visible indicator of the end-point. We could resolve oxygen differences as low as $32 \mathrm{mg} \mathrm{O}_{2}$ $\mathrm{m}^{-3}$; the same level of resolution was achieved using amperometric end-point detection (Schwaerter et al. 1988). The lowest respiration rate measured in the $1 \mu \mathrm{m}$ size-fraction was much higher $\left(148 \mathrm{mg} \mathrm{O}_{2} \mathrm{~m}^{-3} \mathrm{~d}^{-1}\right.$ ) than the precision of the method. The median value of the coefficient of variation of the mean respiration $(\mathrm{CV}=\mathrm{SD} / \overline{\mathrm{x}})$ measured on 8 dates at the 2 sites was $1.8 \%$ in the unfiltered samples, $4.2 \%$ in the $100 \mu \mathrm{m}$ size-fraction and $5.2 \%$ in the $1 \mu \mathrm{m}$ size-fraction.

Phytoplankton biomass (PB) and gross production (PGP). Phytoplankton biomass as chlorophyll a was measured by ethanol extraction of duplicate water samples filtered through GF/C filters (Jespersen \& Christoffersen 1987). Primary production was measured by ${ }^{14} \mathrm{C}$-incorporation into particulate material in $25 \mathrm{ml}$ glass bottles in an incubator following recommendations in Nielsen et al. (1981). Bottles were incubated in duplicate at 10 light levels at photon flux

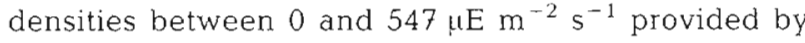
fluorescent-light tubes. Dark fixation rates were subtracted from light fixation rates. Dissolved inorganic carbon was measured on an infrared gas analyzer (Vermaat \& Sand-Jensen 1987).

During $2 \mathrm{~h}$ incubations it is likely that carbon fixation of phytoplankton represents values between net and gross photosynthesis (Harris 1978, Peterson 1980). To calculate gross photosynthesis we used the following procedure. We determined the linear relationship between measured carbon fixation and photon flux density at light limitation [excluding the origo $(0,0)$ ] and determined the negative $y$-intercept. This value was then added to all measured carbon fixation rates to attain gross photosynthesis (Andersen \& Sand-Jensen 1980). Gross photosynthetic rates measured in the incubator were converted to field estimates of gross photosynthesis based on mean hourly measurements of surface photon flux density (photosynthetically active radiation, PAR) and measurements of the vertical light attenuation coefficient by integration over time and depth as previously described (Jensen et al. 1990). For calculation of gross photosynthesis at photon flux densities in the field exceeding those in the incubator the photosynthesis-light curves were extrapolated linearly above the measured photon flux density.

Bacterial biomass (BB) and net production (BNP). Bacterial cell numbers and mean volume were determined by epifluorescence microscopy on formalinfixed preparations of the entire plankton community stained with acridine-orange as previously described (Jensen et al. 1990). Biovolume was converted to carbon biomass by a conversion factor, $0.35 \mathrm{pg} \mathrm{C} \mu \mathrm{m}^{-3}$, found for this particular estuary (Bjørnsen 1986a). Bratbak (1988, his Table 3.3) reached the same mean value comparing carbon:volume conversion factors of formaline and glutaraldehyde fixed bacteria measured by epifluorescence microscopy by several authors.

Bacterial net production was measured by (methyl ${ }^{3} \mathrm{H}$ )thymidine incorporation into cold TCA precipitate (Fuhrman \& Azam 1980) over 30 min incubations with $7.8 \mathrm{nM}$ thymidine. We tested that this thymidine concentration saturated uptake. Triplicate samples and blanks were treated and radioassayed by liquid scintillation counting as described by Jensen et al. (1990). $\left({ }^{3} \mathrm{H}\right)$ thymidine incorporation was converted into cell production applying an emperical factor, $1.1 \times 10^{18}$ cells produced per mol thymidine, determined in the estuary (Riemann et al. 1987), and into carbon production by multiplying by the measured biovolume $0.063 \mu \mathrm{m}^{3}$ cell $^{-1}$ (Jensen et al. 1990) and by $0.35 \mathrm{pg} \mathrm{C}$ $\mu \mathrm{m}^{-3}$ (Bjørnsen 1986a).

\section{RESULTS}

\section{Biomass and productivity of phytoplankton and bacteria}

Both sites showed high levels of phytoplankton and bacterial biomasses and productivities (Table 1). Phytoplankton biomass and gross production at light

Table 1. Phytoplankton biomass (PB, mg chl a $\mathrm{m}^{-3}$ ), phytoplankton gross productivity at light saturation ( $\mathrm{PGP}, \mathrm{mg} \mathrm{C} \mathrm{m}^{-3}$ $\left.\mathrm{h}^{-1}\right)$, bacterial biomass ( $\mathrm{BB}, \mathrm{mg} \mathrm{C} \mathrm{m}^{-3}$ ) and bacterial net production (BNP, mg C m ${ }^{-3} \mathrm{~h}^{-1}$ ), at Stns 1 and 2 in Roskilde Fjord. Mean values and ranges of weekly measurements on 8 dates between July 22 and September 2

\begin{tabular}{|lll|}
\hline Variable & Stn 1 & Stn 2 \\
\hline PB & 22.8 & 7.6 \\
& $7.7-45.2$ & $3.4-11.1$ \\
PGP & 118 & 35 \\
& $36-242$ & $12-62$ \\
BB & 220 & 205 \\
& $32-335$ & $70-297$ \\
BNP & 3.76 & 3.60 \\
& $1.94-6.03$ & $1.01-6.06$ \\
\hline
\end{tabular}

saturation were about 3-fold higher at Stn 1 than at Stn 2. Bacterial biomasses and productivities were about the same at both sites suggesting a relatively greater influence of bacteria in pelagic metabolism at Stn 2. If we assume a C/chl ratio of 30 to 50 in the phytoplankton, the biomass of phytoplankton relative to bacteria will be 3.1 to 5.2 at Stn 1 and 1.1 to 1.9 at Stn 2. A priori, this 
would suggest that bacterial respiration exceeded phytoplankton respiration at Stn 2 which was also supported by later calculations (see below).

\section{Community respiration and respiration in size-fractions}

Mean community respiration was higher at Stn 1 (38.4 $\left.\mathrm{mg} \mathrm{O}_{2} \mathrm{~m}^{-3} \mathrm{~h}^{-1}\right)$ than at $\operatorname{Stn} 2\left(27.7 \mathrm{mg} \mathrm{O}_{2} \mathrm{~m}^{-3} \mathrm{~h}^{-1}\right.$; Table 2). Mean respiration rates were almost as high in

Table 2. Dark respiration rates of the plankton community in unfiltered samples $\left(R_{C}\right)$ and in size-fractions smaller than $100 \mu \mathrm{m}\left(\mathrm{R}_{100}\right)$ and $1 \mu \mathrm{m}\left(\mathrm{R}_{1}\right)$. Mean values $\pm \mathrm{SE}$ and ranges ( $\mathrm{mg} \mathrm{O} \mathrm{O}_{2} \mathrm{~m}^{-3} \mathrm{~h}^{-1}$ ) of weekly measurements on 8 dates between July 22 and September 2 at Stns 1 and 2 in Roskilde Fjord

\begin{tabular}{cccc}
$\begin{array}{c}\text { Site and } \\
\text { variable }\end{array}$ & $\begin{array}{c}\text { Mean value } \\
\pm \mathrm{SE}\end{array}$ & Range & \% of $\mathrm{R}_{\mathrm{C}}$ \\
\hline Stn 1 & & & \\
$\mathrm{R}_{\mathrm{C}}$ & $38.4 \pm 5.4$ & $16.0-57.1$ & 100 \\
$\mathrm{R}_{100}$ & $36.7 \pm 5.3$ & $15.4-54.3$ & 96 \\
$\mathrm{R}_{1}$ & $15.2 \pm 1.7$ & $10.1-23.6$ & 40 \\
$\mathrm{Stn} 2$ & & & \\
$\mathrm{R}_{\mathrm{C}}$ & $27.7 \pm 1.9$ & $17.4-33.8$ & 100 \\
$\mathrm{R}_{100}$ & $25.7 \pm 2.1$ & $17.4-33.8$ & 93 \\
$\mathrm{R}_{1}$ & $13.9 \pm 2.2$ & $6.7-22.9$ & 50 \\
\hline
\end{tabular}

the size-fraction $<100 \mu \mathrm{m}$ as for community respiration (93 to $96 \%$ of $\mathrm{R}_{\mathrm{C}}$ ). Mean respiration rates in the $1 \mu \mathrm{m}$ size-fraction were only slightly higher at Stn $1(15.2 \mathrm{mg}$ $\left.\mathrm{O}_{2} \mathrm{~m}^{-3} \mathrm{~h}^{-1}\right)$ than at $\operatorname{Stn} 2\left(13.9 \mathrm{mg} \mathrm{O}_{2} \mathrm{~m}^{-3} \mathrm{~h}^{-1}\right)$. Thus, respiration rates in the $1 \mu \mathrm{m}$ fraction were $40 \%$ of community respiration at Stn 1 and $50 \%$ at Stn 2 .

\section{Bacterial metabolism}

It is essential for calculation of bacterial respiration in the $1 \mu \mathrm{m}$ size-fraction that no other types of organisms are present here. Heterotrophic nanoflagellates and ciliates are larger than $1 \mu \mathrm{m}$ (Fenchel 1982) and though a few have been found to pass $1 \mu \mathrm{m}$ screens (Andersen 1984, Fuhrman \& McManus 1984) they were only detected after several days of growth and will not produce any measurable interference during $24 \mathrm{~h}$ incubations. However, small photosynthetic cyanobacteria can pass the $1 \mu \mathrm{m}$ filters and contribute to respiration in this size-fraction. We checked this aspect by ${ }^{14} \mathrm{C}$ light incubations of $1 \mu \mathrm{m}$ filtered water. ${ }^{14} \mathrm{C}$ light fixation was slightly higher than ${ }^{14} \mathrm{C}$ dark fixation in the $1 \mu \mathrm{m}$ fraction. Assuming that the dark respiration of these supposedly phototrophs was 5 to $6 \%$ of their lightsaturated photosynthesis (Jensen et al. 1990), these organisms could account for only $1 \%$ of the respiration rates in the $1 \mu \mathrm{m}$ size-fraction. In the following we therefore assume that respiration rates in the $1 \mu \mathrm{m}$ fraction were due to bacteria alone.

Released from the grazing pressure of bacteriovore zooplankton, bacterial biomass may increase in $1 \mu \mathrm{m}$ filtrates during $24 \mathrm{~h}$ dark incubation. Indeed we found on average a 1.59 to 1.67 higher net production of bacteria in the $1 \mu \mathrm{m}$ filtrates after $24 \mathrm{~h}$ dark incubation relative to the initial value (Table 3 ). If this increase

Table 3. Bacterial net production in unfiltered samples ( $B N P_{c}$ ) and in the bacterial size-fraction $(<1 \mu \mathrm{m})$ at the start $\left(\mathrm{BNP}_{1}\right.$ $[0 \mathrm{~h}])$ and after $24 \mathrm{~h}$ incubation ( $\left.\mathrm{BNP}_{1}[24 \mathrm{~h}]\right)$. Phytoplankton gross photosynthesis at light saturation in unfiltered samples $\left(\mathrm{PGP}_{\mathrm{C}}\right)$ and in a size-fraction less than $100 \mu \mathrm{m}\left(\mathrm{PGP}_{100}\right)$. Mean and range of measurements in Roskilde Fjord at Stns 1 and 2 , on 8 dates between July 22 and September 2 . All units in mg

$$
\mathrm{C} \mathrm{m} \mathrm{m}^{-3} \mathrm{~h}^{-1}
$$

\begin{tabular}{lllll|}
\hline Variable & \multicolumn{1}{c}{ Stn 1} & & \multicolumn{1}{c}{ Stn 2} \\
\hline BNP $_{C}$ & 3.76 & $(1.94-6.03)$ & 3.60 & $(1.01-6.06)$ \\
BNP $_{1}(0 \mathrm{~h})$ & 3.15 & $(1.78-5.79)$ & 3.16 & $(1.02-5.97)$ \\
BNP $_{1}(24 \mathrm{~h})$ & 5.29 & $(4.11-8.69)$ & 5.04 & $(3.00-7.29)$ \\
PGP $_{C}$ & 114 & $(36-242)$ & 36 & $(12-63)$ \\
PGP $_{100}$ & 104 & $(31-208)$ & 33 & $(12-63)$ \\
\hline
\end{tabular}

was parallelled by a similar increase in bacterial numbers the mean specific growth rate would be ca $0.5 \mathrm{~d}^{-1}$. This corresponded to growth estimates based upon measured bacterial net production and biomass (see below).

To examine the relationship between bacterial respiration and net production in the $1 \mu \mathrm{m}$ size-fraction the mean values of net production measured initially and after $24 \mathrm{~h}$ were used. Alternatively, we could have calculated the mean net production after $12 \mathrm{~h}$ assuming an exponential increase with time instead of a linear increase. However, because the activity of a single bacterium may change after filtration and because the exact time pattern was not known, the linear approach was used. The approach taken would not alter the subsequent conclusions. Mean bacterial production was only $2 \%$ higher using the linear model instead of the exponential model.

Bacterial respiration and net production in the $1 \mu \mathrm{m}$ size-fraction were significantly linearly related at both sites ( $p<0.001, r^{2}=0.67$; Fig. 1 ). The $y$-intercept was close to zero. The slope of the regression line was $3.02 \pm 0.70(\mathrm{SE}) \mathrm{mg} \mathrm{O} \mathrm{O}_{2}$ respired per $\mathrm{mg} \mathrm{C}$ produced. Assuming a molar ratio of oxygen to carbon of 1.0 , the mean growth efficiency was $46.9 \%$. Using all the paired measurements of bacterial respiration and net production the mean growth yield was $45.2 \pm$ $1.4 \%(\mathrm{SE})$ at $\operatorname{Stn} 1$ and $45.6 \pm 2.8 \%(\mathrm{SE})$ at $\operatorname{Stn} 2$. 
Fig. 1 Relationship between bacterial respiration and net production, in the $1 \mu \mathrm{m}$ size-fraction, at Stns 1 and 2

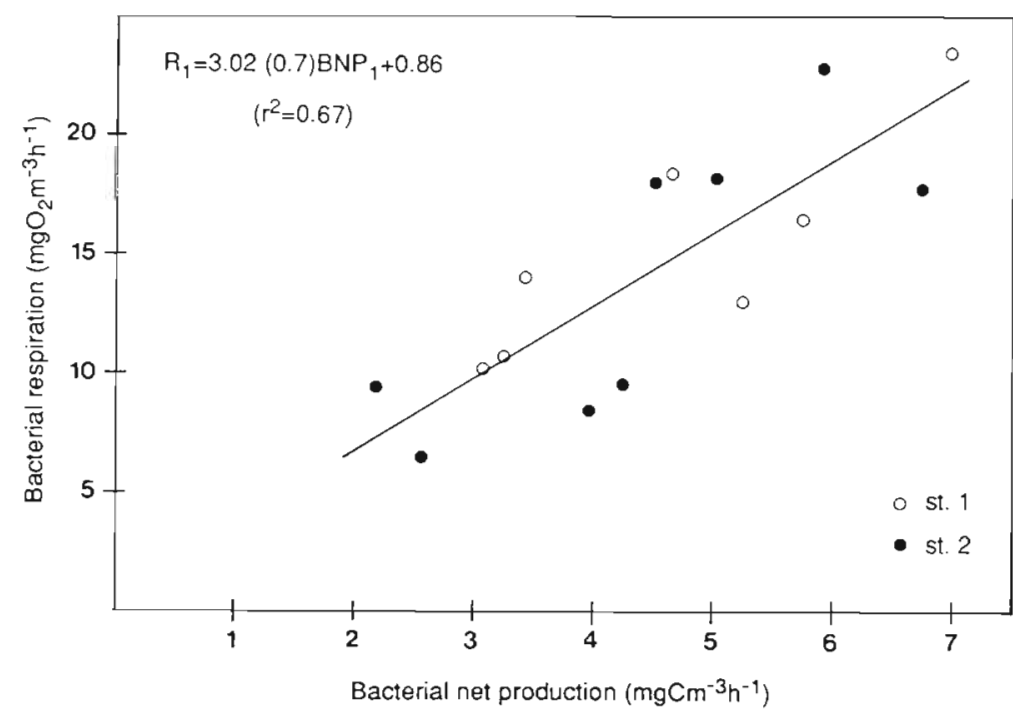

plankton biomass may covary with the phytoplankton biomass. If phytoplankton and zooplankton biomasses are positively interrelated we would tend to overestimate phytoplankton respiration and underestimate zooplankton respiration. However, we have no reason to believe that this covariation existed at the 2 sites during the short investigation period. Macrozooplankton have long generation times relative to the rapid fluctuations of phytoplankton biomass. Phytoplankton and bacteria biomasses showed no simple interdependent time pattern (Jensen et al. 1987) and accordingly covariation between phytoplankton respiration and respiration of bacteriovore zooplankton should not be expected.

The linear relationships of $R_{C}-R_{B}$ versus $P G P$ and $P B$ were highly significant at Stn 1 (Table $4 ; r^{2}=0.90$ ). The relationships were also positive at $S t n 2$ but correlations were weaker particularly for $R_{C}-R_{B}$ versus $P B$ which was therefore not considered any further. Phytoplankton respiration rates were $6.1 \%$ (Stn 1) and $7.8 \%$ (Stn 2) of light-saturated gross photosynthesis according to the slope of $R_{C}-R_{B}$ versus PGP. These values corresponded with previous calculations of phytoplankton respiration in this estuary as well as with literature values (Jensen et al. 1990). The estimated mean phytoplankton respiration rates were 19.2 and $20.0 \mathrm{mg} \mathrm{O}$ $\mathrm{m}^{-3} \mathrm{~h}^{-1}$ at Stn 1 according to the 2 regression analysis and $7.8 \mathrm{mg} \mathrm{O}_{2} \mathrm{~m}^{-3} \mathrm{~h}^{-1}$ at Stn 2. Background respiration not accounted for by phytoplankton provided an estimate of zooplankton respiration rates at 5.0 and $5.8 \mathrm{mg}$ $\mathrm{O}_{2} \mathrm{~m}^{-3} \mathrm{~h}^{-1}$ (Stn 1) and $7.6 \mathrm{mg} \mathrm{O}_{2} \mathrm{~m}^{-3} \mathrm{~h}^{-1}$ (Stn 2). In the subsequent analysis we used the values attained by the relationship of $R_{C}-R_{B}$ versus PGP because of the better fit.

The overall contributions of phytoplankters, bacteria and zooplankters to community respiration are shown in Table 5. At Stn 1 phytoplankters were responsible 
Table 4. Results of linear regression analysis of community respiration minus bacterial respiration $\left(\mathrm{R}_{\mathrm{C}}-\mathrm{R}_{\mathrm{B}}, \mathrm{mg} \mathrm{O}_{2} \mathrm{~m}^{-3} \mathrm{~h}^{-1}\right)$ versus light-saturated gross photosynthesis ( $\mathrm{PGP}, \mathrm{mg} \mathrm{C} \mathrm{m}^{-3} \mathrm{~h}^{-1}$ ) and chlorophyll concentration ( $\mathrm{PB}, \mathrm{mg} c \mathrm{ch}$ a $\mathrm{m}^{-3}$ ). Mean values, slopes ( $\mathrm{mg} \mathrm{O} \mathrm{O}_{2} \mathrm{mg}^{-1} \mathrm{O}_{2}$ and $\mathrm{mg} \mathrm{O}_{2} \mathrm{mg}^{-1} \mathrm{chl} \mathrm{h}{ }^{-1}$ ), y-intercept (background respiration, $\mathrm{mg} \mathrm{O}_{2} \mathrm{~m}^{-3} \mathrm{~h}^{-1}$ ) and correlation coefficients of the regressions are shown. Carbon-based production was converted to oxygen assuming at 1.0 molar ratio. Mean phytoplankton respiration $\left(\mathrm{R}_{\mathrm{p}} \mathrm{mg} \mathrm{O} \mathrm{O}_{2} \mathrm{~m}^{-3} \mathrm{~h}^{-1}\right.$ ) was calculated as the mean $\mathrm{x}$-value times the slope. Bacterial respiration was calculated as described in the text

\begin{tabular}{|c|c|c|c|c|c|c|}
\hline Variable & $\begin{array}{l}R_{C}-R_{B} \\
\text { vs PGP }\end{array}$ & $\begin{array}{c}\text { Stn } 1 \\
R_{C}-R_{B} \\
\text { vs PB }\end{array}$ & $\begin{array}{l}\text { Mean } \\
\text { level }\end{array}$ & $\begin{array}{l}R_{C}-R_{B} \\
\text { vs PGP }\end{array}$ & $\begin{array}{c}\text { Stn } 2 \\
R_{C}-R_{B} \\
\text { vs PB }\end{array}$ & $\begin{array}{l}\text { Mean } \\
\text { level }\end{array}$ \\
\hline$R_{C}-R_{B}$ & & & 25.0 & & & 15.4 \\
\hline PGP & & & 118.2 & & & 37.2 \\
\hline $\mathrm{PB}$ & & & 22.8 & & & 7.6 \\
\hline Slope & 0.061 & 0.88 & & 0.078 & 0.58 & \\
\hline $\mathrm{Y}$-intercept & 5.8 & 5.0 & & 7.6 & 11.0 & \\
\hline $\mathrm{R}_{\mathrm{p}}$ & 19.2 & 20.0 & & 7.77 & 4.45 & \\
\hline Correlation coefficient & 0.95 & 0.95 & & 0.52 & 0.25 & \\
\hline
\end{tabular}

Table 5. Community respiration and respiration rates of phytoplankton, bacteria and zooplankton. Bacterial respiration was measured in the $<1 \mu \mathrm{m}$ size-fraction and corrected for the presence of larger bacteria and the increase in bacterial activity during $24 \mathrm{~h}$ incubation in $1 \mu \mathrm{m}$ filtered water Phytoplankton and zooplankton respiration were calculated from the linear regression analysis of community respiration minus bacterial respiration versus phytoplankton gross photosynthesis in Table 4. Respiration of heterotrophic nanoflagellates was estimated assuming that they consumed the entire bacterial production and respired $60 \%$ of this. All values are averages for the period July 22 to September 2 in $\mathrm{mg} \mathrm{O}_{2} \mathrm{~m}^{-3}$ $\mathrm{h}^{-1}$ Percentages of community respiration in parenthesis. Further information in text

\begin{tabular}{|ccccc|}
\hline Commun. & Phytopl. & Bact. & Zoopl. & Nanofl. \\
\hline Stn 1 & & & & \\
38.4 & 19.2 & 13.4 & 5.8 & 6.0 \\
$(100)$ & $(50)$ & $(35)$ & $(15)$ & $(16)$ \\
Stn 2 & & & & \\
27.7 & 7.8 & 12.3 & 7.6 & 5.7 \\
$(100)$ & $(28)$ & $(44)$ & $(27)$ & $(21)$ \\
\hline
\end{tabular}

for $50 \%$ of $\mathrm{R}_{\mathrm{C}}$, bacteria for $35 \%$ and zooplankters for $15 \%$. At $\operatorname{Stn} 2$ phytoplankters were responsible for $28 \%$ of $\mathrm{R}_{\mathrm{C}}$, bacteria for $44 \%$ and zooplankters for $27 \%$. Thus, phytoplankters were more important in the respiratory budget at $\operatorname{Stn} 1$ than at $\operatorname{Stn} 2$ in agreement with the 3 -fold higher biomasses at the former locality. Bacteria on the other hand were more important at Stn 2 in agreement with the similar bacterial biomass and production levels at the 2 localities. Finally, zooplankters were significant components of the respiratory budget at both sites.

Not all of phytoplankton net production is consumed and respired by heterotrophs in the pelagial. Phytoplankters are lost extensively by sedimentation and by grazing of benthic filter-feeders (Kanneworff \& Kamp-
Nielsen unpubl.). Part of the particulate production is also lost to more nutrient-poor neighbouring regions by advection and mixing. Bacteria, on the other hand, are probably not lost to the sediment or to benthic filterfeeders. Moreover, the bacterial net production was high and no significant changes in bacterial biomass took place between the start and the end of the observation period. Accordingly there needs to be room in the respiratory budget for considerable metabolism of bacteriovore zooplankters. If we assume that the entire bacterial production is converted by pelagial nanoflagellates growing at an efficiency of $40 \%$ (Fenchel 1982) we reach an estimate of nanoflagellate respiration of $6.0 \mathrm{mg} \mathrm{O}_{2} \mathrm{~m}^{-3} \mathrm{~h}^{-1}$ (Stn 1) and $5.1 \mathrm{mg} \mathrm{O}_{2} \mathrm{~m}^{-3} \mathrm{~h}^{-1}$ (Stn 2; Table 5). According to these estimates there is no room (Stn 1) or little room $\left(1.9 \mathrm{mg} \mathrm{O}_{2} \mathrm{~m}^{-3} \mathrm{~h}^{-1}\right.$ at Stn 2) for respiratory losses by other zooplankton organisms.

\section{Phytoplankton production and respiration in the pelagial and the sediment}

Integrated rates of production and respiration in the water column and sediment respiration are shown in Fig. 2. Phytoplankton gross photosynthesis was about twice as high at Stn 1 than at Stn 2. Phytoplankton gross production was balanced by respiration in the water column and the sediment at Stn 1. Phytoplankton gross production and pelagial respiration balanced each other at Stn 2. Including sediment respiration the respiratory processes, therefore, exceeded phytoplankton gross production. However, this was only a temporary phenomenon. During the period April 15 to September 2 phytoplankton gross production exceeded total pelagic and sediment respiration at $\operatorname{Stn} 2$ by $10 \%$ (Table 7 in Jensen et al. 1990) Because of the high 


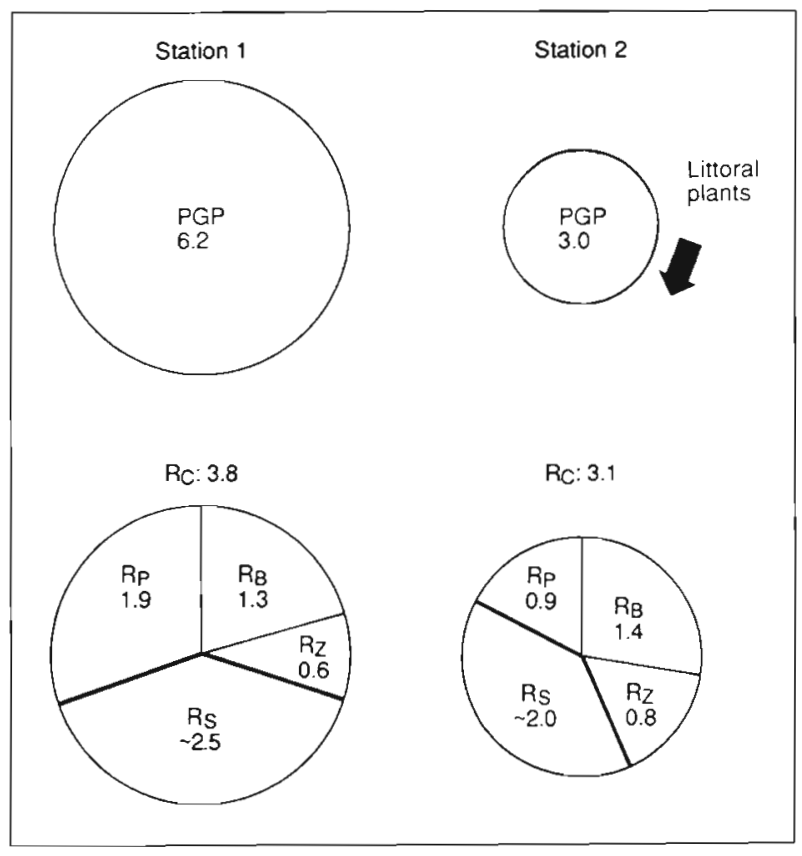

Fig. 2. Phytoplankton gross productivity (PGP), respiration of phytoplankton $\left(R_{P}\right)$ bacteria $\left(R_{B}\right)$ and zooplankton $\left(R_{Z}\right)$ in the water column $\left(R_{C}=R_{p}+R_{B}+R_{Z}\right)$ and sediment respiration $\left(R_{S}\right)$ at Stns 1 and 2. Mean values for 8 dates between July 22 and September 2. Sediment respiration rates are estimates from Kanneworff, Kamp-Nielsen \& Nielsen (unpubl.). Conversion from carbon units was based on a molar ratio of $\mathrm{O}_{2}$ to $\mathrm{C}$ of 1.0. Integrated values of bacterial metabolism (not shown in the figure) were mean bacterial net production ( $\pm \mathrm{SE}$ ): $0.98 \pm 0.18(S \operatorname{stn} 1)$ and $1.06 \pm 0.20(\mathrm{Stn} 2)$ and mean bacterial gross production 2.30 (Stn 1) and 2.42 (Stn 2). All units are in $\mathrm{g} \mathrm{O}_{2} \mathrm{~m}^{-2} \mathrm{~d}^{-1}$

phytoplankton biomasses at Stn 1 and the associated high light attenuation with depth there was no significant contribution of littoral algae and rooted plants to the organic pool in water and sediment. In the large broad where Stn 2 was located, however, gross production of littoral plants was $35 \%$ of gross production of phytoplankton on an annual basis (Borum et al. unpubl.) and this production of organic matter may contribute to the metabolism in water and sediment at the deepest spot where Stn 2 was located even though littoral plants did not penetrate that deep.

Phytoplankton respiration was a major process in pelagial community respiration and a significant proportion of the phytoplankton gross production $130.5 \%$ at $\operatorname{Stn} 1,28.5 \%$ at $\operatorname{Stn} 2$ ) was respired directly by the algae. It also appears from the budget that bacterial metabolism was very important in the pelagic environment. Bacterial net production was $16 \%$ of phytoplankton gross production at Stn 1 and $35 \%$ at Stn 2 . The carbon flux through the bacteria (bacterial gross production) was $37 \%$ of phytoplankton gross production at Stn 1 and $80 \%$ at Stn 2 .

\section{DISCUSSION}

\section{Bacterial metabolism}

Three independent methods testified the major importance of small free-living bacteria in pelagial metabolism in Roskilde Fjord. Bacterial biomasses were high approaching the estimated phytoplankton carbon biomass at $\operatorname{Stn} 2$, bacterial net production in the water column was $16 \%$ (Stn 1) and $35 \%$ (Stn 2) of phytoplankton gross production and respiration rates in $1 \mu \mathrm{m}$ filtrates were $40 \%$ (Stn 1) and $50 \%$ (Stn 2) of community respiration. Two important conversion factors are involved in calculations of bacterial biomass and net production, i.e. the carbon content per unit volume and the number of cells produced per mol thymidine incorporated into macromolecules. Both conversion factors vary considerably in the literature (Cole et al. 1989). We here used conversion factors derived from studies in Roskilde Fjord (Bjørnsen 1986a, Riemann et al. 1987). The carbon conversion factor used $(0.35 \mathrm{pg} \mathrm{C}$ $\mu^{-3}$ ) is in the middle of the range of recent direct measurements (Bjornsen 1986a, Bratbak 1988). It is important to realize that the conversion factor is valid only for conversion between carbon content and bacterial volume measured under the epifluorescent microscope. The carbon: volume ratio of natural bacteria is probably lower $\left(0.22 \mathrm{pgC}_{\mu \mathrm{m}^{-3}}\right.$; Bratbak 1985) because of cell shrinkage caused by fixation and preparation of samples for microscopy. The thymidine conversion factor $\left(1.1 \times 10^{18}\right.$ cells $\left.\mathrm{mol}^{-1}\right)$ applied is lower than those used by most other investigators (Cole et al. 1989). Thus using the arguments forwarded by Cole et al. (1989) based on the carbon balance sheet from Mirror Lake, New Hampshire, our 2 conversion factors in combination are certainly realistic and lead to similar or lower estimates of bacterial net production than most other conversion factors applied.

Bacterial net production varied linearly with respiration rate in the $1 \mu \mathrm{m}$ filtrate and from the slope of this relationship, we calculated a mean growth yield of $46.9 \%$. This estimate of bacterial growth yield is sensitive to the conversion factors used for calculating bacterial carbon production from short-term thymidine incorporation as well as the applied molar ratio of oxygen to carbon. The bacterial growth yield, for example, would increase to about $52 \%$ if we applied a $\mathrm{O}_{2}$ : C ratio of 1.25 instead of 1.0 . The estimated bacterial growth yield was the same as that determined by Cole et al. (1984) in Mirror Lake during summer and it is close to those efficiences (50 to $60 \%$; Calow 1977) generally applied. Nevertheless, it would be desirable to perform all measurements in carbon units and use a direct determination of bacterial carbon production. This approach was taken by Bjørnsen (1986b) growing 
free-living bacteria in continuous cultures fed with filtered seawater from Roskilde Fjord. Bjornsen (1986b) reached much lower estimates of bacterial growth yield $(21 \%)$. His approach was good but some methodological problems may still have remained (e.g. possible growth of bacteria on wall surfaces, bacterial mortality by viruses; Bergh et al. 1989). Also, by removing the algae by filtration the medium may become depleted with $\mathrm{N}$-rich amino acids which may lead to higher respiratory rates of bacteria relative to their growth. Goldman et al. (1987) recently showed that bacterial growth yield is certainly not constant but depends on substrate $C: N$ ratios.

We may ask whether a bacterial growth yield of $21 \%$ could be compatible with our findings. If our measurements of bacterial respiration in the $1 \mu \mathrm{m}$ filtrates are correct (the reproducibility was good and no conversion factors except for the molar $\mathrm{O}_{2}: \mathrm{C}$ ratio are involved) we would thus need to accept that bacterial net production was overestimated by a factor of 3.3 This is hard to believe considering that the 2 conversion factors in combination were lower than factors used by most other investigators. In any case overestimation may result from application of a too high carbon or thymidine conversion factor or a combination of both. Changes in the carbon conversion factor would change bacterial net production and bacterial biomass equally, whereas changes in the thymidine conversion factor would not affect the bacterial biomass. From Table 1 we estimate a mean specific growth rate at $0.41 \mathrm{~d}^{-1}$, applying the mean values of bacterial biomass and the original estimate of bacterial net production. Thus a 3.3-fold lower thymidine conversion factor would lead to a mean specific growth rate of $0.12 \mathrm{~d}^{-1}$ (generation time $5.6 \mathrm{~d}$ ). This growth rate seems unacceptably low considering the rates usually attained in filtered coastal water from eutrophic regions at 15 to $20^{\circ} \mathrm{C}$ (Riemann et al. 1987) and during natural growth cycles (oscillating with bacteriovore nanoflagellates) in other coastal Danish waters during summer (Andersen \& Fenchel 1985, Andersen \& Sørensen 1986). Applying a 3.3-fold lower carbon conversion factor (i.e. $0.11 \mathrm{pg} \mathrm{C}$ $\left.\mu \mathrm{m}^{-3}\right)$, would not alter the specific growth rate, but bacterial net production in the water column would then be only $5 \%$ (Stn 1) and $11 \%$ (Stn 2) of phytoplankton gross production. This seems unacceptably low considering that we examined a summer period and that the annual mean value observed in the broadscale review of Cole et al. (1988) was $30 \%$. We therefore conclude that our bacterial production rates and growth yield at $46.9 \%$ represent our best estimates considering the measured phytoplankton production and previous estimates of bacterial growth yield.

Bacterial metabolism relative to phytoplankton biomass and production was much higher at Stn 2 than at
Stn 1 in Roskilde Fjord. The most likely explanation for this pattern is an additional supply of organic substrates from littoral algae and rooted macrophytes in the $40 \mathrm{~km}^{2}$ large broad where Stn 2 was located at the deepest spot. Moreover frequent resuspension of surface sediments and subsequent input of organic substrates occured at Stn 2 but not at Stn 1 which was located in a smaller and more protected broad.

\section{Pelagial metabolism and implications for food webs}

Phytoplankton, bacteria and zooplankton were all important components of pelagic community respiration with phytoplankton and bacteria as the main respiring organisms. The distribution of respiratory activity among organisms corresponded with those observed by Williams (1981) in coastal marine waters and by Schwaerter et al. (1988) in eutrophic lakes during summer

It is common practice to assume that ${ }^{14} \mathrm{C}$ light fixation of phytoplankton measures net production and also to use this value as an estimate of daily net production. This is a problematic procedure. Phytoplankton respiration is often the single most important loss process of primary production (Tilzer 1984, Forsberg 1985). In Roskilde Fjord during late summer, for example, about $30 \%$ of phytoplankton gross production was respired by the algae, constituting $50 \%$ (Stn 1) and $28 \%$ (Stn 2) of community respiration.

Zooplankton respiration was estimated to 5.8 and $7.6 \mathrm{mg} \mathrm{O}_{2} \mathrm{~m}^{-3} \mathrm{~h}^{-1}$. If bacteriovore nanoflagellates consumed the entire bacterial production and respired $60 \%$ of this, their respiration alone would be 5.7 and $6.0 \mathrm{mg} \mathrm{O} \mathrm{m}^{-3} \mathrm{~h}^{-1}$. Alternatively if zooplankton respired the entire bacterial production, this would amount to 9.5 and $10.0 \mathrm{mg} \mathrm{O} \mathrm{O}_{2}^{-3} \mathrm{~h}^{-1}$, thus exceeding the estimated total zooplankton respiration. We are unable to evaluate the exact fate of bacterial production. Part of bacterial net production may be lost by viral infection and respired by other bacteria. Organic compounds are also lost in the microbial food web and recycled back to the bacteria. Though our estimates of zooplankton respiration appear to be low they may therefore be correct after all. Similar patterns though with slightly higher respiratory activity ascribed to zooplankton were previously estimated in Roskilde Fjord, i.e. 17 to $22 \%$ of community respiration at Stn 1 and 28 to $36 \%$ at Stn 2 (Jensen et al. 1990).

There is little room in the respiratory budget for respiration of micro- and macrozooplankton feeding directly on algae. This accords with the observation of very sparse macrozooplankton populations in Roskilde Fjord (Horsted et al. 1988, Riemann et al. 1988). At a locality $10 \mathrm{~km}$ north of $\mathrm{Stn} 2$ the macrozooplankton 
biomass (>45 $\mu \mathrm{m}$ ) was only 9 (April), 20 (June) and $4 \mathrm{mg} \mathrm{C} \mathrm{m}{ }^{-3}$ (September; Horsted et al. 1988, see also Table 1). If we use these biomass levels of macrozooplankton to estimate macrozooplankton respiration we attain values which are insignificant relative to the measured mean community respiration of 27.7 (Stn 2) and $38.4 \mathrm{mg} \mathrm{O}_{2} \mathrm{~m}^{-3} \mathrm{~h}^{-1}(\mathrm{Stn} 1)$. The measured maximum biomass of the only copepod present (Acartia tonsa) was $2.2 \mathrm{mg} \mathrm{C} \mathrm{m}^{-3}$. According to Kiørboe et al. (1985) the respiration rate of $A$. tonsa under optimum feeding conditions at this biomass level would be $0.03 \mathrm{mg} \mathrm{O}_{2} \mathrm{~m}^{-3} \mathrm{~h}^{-1}$. Accounting for the presence of other macrozooplankton organisms $(>45 \mu \mathrm{m})$ and applying the same specific rates of respiration the maximum respiration rates of the entire macrozooplankton community at peak abundance would be $0.3 \mathrm{mg} \mathrm{O}_{2}$ $\mathrm{m}^{-3} \mathrm{~h}^{-1}$ or ca $1 \%$ of community respiration. Thus the main loss processes of phytoplankton production appear to be respiration by the algae themselves, bacterial respiration and respiration by benthic organisms. The importance of benthic processes is expected from the shallow nature of the estuary, the dense communities of benthic filter-feeders (particularly at Stn 2) and high sediment respiration rates. The importance of mussel populations for regulation of phytoplankton abundance was also demonstrated in large seawater enclosures in Roskilde Fjord (Riemann et al. 1988). We acknowledge the uncertainties in our estimates of micro- and macrozooplanktons respiration, however, and recommend a direct approach to determine the consumption and respiratory activity of these organisms.

In conclusion our data suggest that respiration of phytoplankton and bacteria constituted the major carbon loss in pelagial waters at 2 sites in the eutrophic estuary during late summer. Benthic and pelagic metabolism were tightly interrelated in the shallow environment and to describe pelagic carbon fluxes the benthic environment needs to be considered. Considering the complex structure of food webs (Sherr \& Sherr 1988) there is a gap between operational analysis of biomass, production and respiration of pelagic organisms and proper evaluation or testable models of carbon fluxes and regulations in the food web. We also suggest that future studies should consider more carefully the ingestion and respiration of macrozooplankton and the possible internal circulation of organic compounds among bacteria through autolysis or viral infection.

Acknowledgements. We thank P. K. Bjørnsen and F. Pedersen for help during the work and P. K. Bjørnsen and M. Sondergaard and 2 anonymous reviewers for constructive criticism of the manuscript

\section{LITERATURE CITED}

Andersen, J. M., Sand-Jensen, K. (1980). Discrepancies between the $\mathrm{O}_{2}$ and ${ }^{14} \mathrm{C}$ methods for measuring phytoplankton gross photosynthesis at low light levels. Oikos 35: 3.59-364

Andersen, P. (1984). En undersøgelse af de heterotrofe microflagellaters okologi med særlig henblik på deres rolle som græssere på de planktoniske bakterier. MS thesis, Institute of Genetics and Ecology, Univ. of Aarhus

Andersen, P., Fenchel, T (1985). Bacteriovory by microheterotrophic flagellates in seawater samples. Limnol. Oceanogr. 30: 198-202

Andersen, P., Sorensen, H. M. (1986). Population dynamics and trophic coupling in pelagic microorganisms in eutrophic coastal waters. Mar. Ecol. Prog. Ser. 33: 99-109

Bergh, $\varnothing$., Børsheim, K. Y., Bratbak, G., Heldal, M. (1989). High abundance of viruses found in aquatic environments. Nature, Lond. 340: 467-468

Bjornsen, P. K. (1986a). Automatic determination of bacterioplankton biomass by image analysis. Appl. environ. Microbiol. 51: 1199-1204

Bjornsen, P. K. (1986b). Bacterioplankton growth yield in continuous seawater cultures. Mar Ecol. Prog. Ser. 30: 191-196

Bjornsen, P. K. (1987). Bakterieplanktonets rolle i de frie vandmassers stofomsætning. Ph.D. thesis, Freshwater Biological Laboratory, Univ. of Copenhagen

Borum, J. (1985). Development of epiphytic communities on eelgrass (Zostera marina) along a nutrient gradient in a Danish estuary. Mar. Biol. 87: 223-241

Bratbak, G. (1985). Bacterial biovolume and biomass estimations. Appl. environ. Microbiol. 49: 1488-1493

Bratbak, G. (1988). Production, amount and fate of bacterial biomass in marine waters. Dissertation, Dept Microbiology and Plant Physiology, Univ. of Bergen

Calow, P. (1977). Conversion efficiencies in heterotrophic organisms. Biol. Rev. 52: 385-409

Carman, K. R., Dobbs, F. C., Guckert, J. B. (1988). Consequences of thymidine catabolism for estimates of bacterial production: an example from a coastal marine sediment. Limnol. Oceanogr. 33: 1595-1606

Cole, J. J., Caraco, N. F., Strayer, D. L., Ochs, C., Nolan, S. (1989). A detailed organic carbon budget as an ecosystemlevel calibration of bacterial respiration in an oligotrophic lake during midsummer. Limnol. Oceanogr. 34: 286-296

Cole, J. J., Findlay, S., Pace, M. L. (1988). Bacterial production in fresh and saltwater ecosystems; a cross system overview. Mar. Ecol. Prog. Ser. 43: 1-10

Cole, J. J., Likens, G. E. Hobbie, J. E. (1984). Decomposition of planktonic algae in an oligotrophic lake. Oikos 42: $257-266$

Ducklow, H. W., Hill, S. M. (1985). The growth of heterotrophic bacteria in the surface waters of warm core rings. Limnol. Oceanogr. 30: 239-259

Fenchel, T (1982). Ecology of heterotrophic microflagellates. 2. Bioenergetics and growth. Mar. Ecol. Prog. Ser. 8: 225-231

Forsberg, B. R. (1985). The fate of planktonic primary production. Limnol. Oceanogr. 30: 807-819

Fuhrman, J. A., Azam, F. (1980). Bacterioplankton secondary production estimates for coastal waters of British Columbia, Antarctica and California. Appl. environ. Micribiol. 39 : 1085-1095

Fuhrman, J. A., Azam, F. (1982). Thymidine incorporation as a measure of heterotrophic bacterioplankton production in marine surface waters: evaluation and field results. Mar. Biol. 66: 109-120 
Fuhrman, J. A., McManus, G. B. (1984). Do bacteria-sized eukaryotes consume significant bacterial production. Science 224: $1257-1260$

Goldman, J. C., Caron, D. A., Dennett, M. R. (1987). Regulation of gross growth efficiency and ammonium regeneration in bacteria by substrate C:N Limnol. Oceanogr. 32 $1239-1252$

Harris, G. P. (1978). Photosynthesis, productivity and growth the physiological ecology of phytoplankton. Arch. Hydrobiol. (Beih. Ergeb. Limnol.) 10: 1-171

Horsted, S. J., Nielsen, T. G., Riemann, B., Pock-Steen, J. Bjornsen, P. K. (1988). Regulation of zooplankton by suspension-feeding bivalves and fish in estuarine enclosures. Mar. Ecol. Prog. Ser 48: 217-224

Jensen, L. M., Marcher, S., Hansen, M. (1987). Produktion og omsætning of organisk stof i de frie vandmasser i Roskilde Fjord. MS thesis, Freshwater Biological Laboratory, Univ of Copenhagen

Jensen, L. M., Sand-Jensen, K., Marcher, S., Hansen, M (1990). Plankton community respiration along a nutrient gradient in a shallow Danish estuary. Mar. Ecol. Prog. Ser 61: 75-85

Jespersen, A., Christoffersen, K. (1987). Measurements of chlorophyll-a from phytoplankton using ethanol as extraction solvent. Arch. Hydrobiol 109: 445-454

Kiørboe, T., Mohlenberg, T., Hamburger, K. (1985). Bioenergetics of the planktonic copepod Acartia tonsa: relation between feeding, egg production and respiration, and composition of specific dynamic action. Mar. Ecol. Prog. Ser. 26: 85-99

Lancelot, C., Billen, G. (1984). Activity of heterotrophic bacteria and its coupling to primary production during the spring phytoplankton bloom in the southern bight of the North Sea. Limnol. Oceanogr 29: 721-730

Larsson, U., Hagström, A. (1982). Fractionated phytoplankton primary production, exudate release and bacterial production in a Baltic eutrophication gradient. Mar. Biol. 67: $57-70$

Nielsen, G. £., Jacobsen, T S., Gargas, E., Buch, E. (1981). The Belt Project. Evaluation of physical, chemical and biological measurements. The National Agency of Environmental Protection, Denmark

Peters, R. H. (1986). The role of prediction in limnology. Limnol. Oceanogr. 31: 1143-1159

Peterson, B. J. (1980). Aquatic primary productivity and the ${ }^{14} \mathrm{CO}_{2}$ method: a history of the productivity problem. Ann Rev. Ecol. Syst. 11: 359-385

Riemann, B., Søndergaard, M. (1984). Measurements of diel

This article was submitted to the editor rates of bacterial secondary production in aquatic environments. Appl. environ. Microbiol. 47: 632-638

Riemann, B., Søndergaard, M. (1986). Regulation of bacterial secondary production in two eutrophic lakes and in experimental enclosures. J. Plankton Res. 8: 519-536

Riemann, B., Bjørnsen, P. K., Newell, S., Fallon, R. (1987). Calculation of cell production of coastal marine bacteria based on measured incorporation of ${ }^{3} \mathrm{H}$-thymidine. Limnol. Oceanogr. 32: 471-476

Riemann, B., Nielsen, T. G., Horsted, S. J., Bjørnsen, P. K., PockSteen, J. (1988). Regulation of phytoplankton biomass in estuarine enclosures. Mar. Ecol. Prog. Ser. 48: 205-215

Robarts, R. D. Wicks, R. J. (1989). [Methyl- ${ }^{3} \mathrm{H}$ ] thymidine macromolecular incorporation and lipid labeling: their significance to DNA labeling during measurements of aquatic bacterial growth rate. Limnol. Oceanogr $34 ; 213-222$

Scavia, D. (1988). On the role of bacteria in secondary production. Limnol. Oceanogr. 33: 1220-1224

Schwaerter, S., Sondergaard, M., Riemann, B., Jensen, L. M. (1988). Respiration in eutrophic lakes: the contribution of bacterioplankton and bacterial growth yield. J. Plankton Res. 10: 515-531

Sherr, E., Sherr, B. (1988). Role of microbes in pelagic food webs: a revised concept. Limnol. Oceanogr. 33: 1225-1227

Simon, M., Tilzer, M. M. (1987). Bacterial response to seasonal changes in primary production and phytoplankton biomass in Lake Constance. J. Plankton Res. 9: 535-552

Strayer, D. (1988). On the limits to secondary production. Limnol. Oceanogr. 33: 1217-1220

Tilzer, M. M. (1984). Estimation of phytoplankton loss rates from daily photosynthetic rates and observed biomass changes in Lake Constance. Limnol. Oceanogr. 28: 833-846

Vermaat, J. E., Sand-Jensen, K (1987). Survival, metabolism and growth of Ulva lactuca under winter conditions; a laboratory study of bottlenecks in the life cycles. Mar. Biol. 95: 55-61

Watson, S. W., Novitzky, I J., Ouinby, H. L., Valois, F. W. (1977). Determination of bacterial number and biomass in the marine environment. Appl. environ. Microbiol. 33: 940-946

Williams, P. J. leB. (1981). Microbial contribution to overall marine plankton metabolism: direct measurements of respiration. Oceanol. Acta 4: 359-364

Williams, P. J. leB. (1984). A review of measurements of respiration rates of marine plankton populations. In: Hobbie J. E., Williams, P. J. leB. (eds.) Heterotrophic activity in the sea. Plenum Press, New York, p. 357-389

Manuscript first received: November 24, 1989

Revised version accepted: May 3,1990 